RESEARCH PAPER

\title{
Agriculture supply chain management - an operational perspective
}

\author{
Mahak Bhatia', G.M. Janardhana ${ }^{1}$ \\ ${ }^{1}$ Bhartiya Skill Development University Rajasthan, Jaipur, India.
}

How to cite: Bhatia, M. and Janardhana, G.M. (2020). "Agriculture supply chain management - an operational perspective", Brazilian Journal of Operations \& Production Management, Vol. 17, No. 4, e2020978.

https://doi.org/10.14488/BJOPM.2020.043

\begin{abstract}
Goal: An integrated model for production and distribution of agricultural produce is developed. The objective of mathematical model formulated is to maximize farm revenues by investigating the production and logistics parameters associated with the type of crop cultivated. The paper aims to develop a mathematical \& conceptual framework for crop distribution that will provide an optimal farm return with the reduction in farm cost.

Design / Methodology / Approach: Mathematical and conceptual model is developed to overcome the challenges faced by growers of perishable crops. The decision of model is made on the basis of traditional/ previous season factors such as resource availability, market price of the produce in previous year. Linear Programming as a tool is used for formulation.

Results: The complexity of model depends on the type of crop cultivated and capital invested by the growers. The developed model thus results in, planning a farm model from cultivation till harvesting. The timing which is an important parameter in the case of perishable crops were taken under formulation.

Limitations of the investigation: To analyze the different parameters affecting the decision variables a hypothetical farm planting tomatoes, cucumbers and bell peppers are taken under considered to determine the operational cost involved in logistics management of perishable crops. Only the perishable crops were considered to study so that the complexities and the constraints associated in packaging, storage and harvesting of these crops will be observed and analyzed. Most of these farm model often overviews the factor such as product deterioration, product life span, freshness \& quality, price dynamics, transportation and inventory costs.

Practical implications: The study supports the farmers practising perishable crops, to maximize the farm revenue and minimize the farm losses. The developed model will help the growers of perishable produce to analyze the scenario and consider the crop according to the market demands and available farm resources.

Originality / Value: none of the studies conducted so far will simultaneously focus on minimization of product loss and maximization of farm revenues
\end{abstract}

Keywords: Logistics; Inventory; Agri-supply chain; Mathematical model; Distribution; Production; Perishable crop.

\section{INTRODUCTION}

According to the Indian Ministry of Trade \& Industry, about 20\% of the farm produced gets wasted every year due to a lack of storage facilities (CSR Journal, 2018). A survey has been conducted to investigate the problem present in the agri-supply chain management system.

Financial support: None.

Conflict of interest: The authors have no conflict of interest to declare.

Corresponding author: mahakbhatia30@gmail.com

Received: 24 May 2020

Approved: 20 Aug 2020

Editor: Osvaldo L. G. Quelhas. 
The gaps that affect the supply chain system includes improper handling of agricultural produce, the involvement of intermediaries that mislead the farmers; results in the lower price of their agricultural produce, increase in post-harvest losses due to inappropriate availability of tools, inaccessibility of markets \& mandis and lastly the lack of knowledge regarding government schemes and policies makes the sector more challenging and complex.

Because of these gaps in a system, the need for proper regulations is required to overcome the agricultural loss. Consequently, the need and challenge to overcome the food wastage and spoilage have been evolved. However, adapting traditional planning to a fresh Agri supply chain is a task whose complexity is accompanied by the perishability of the crops.

(Lowe and Preckel, 2004) mention long supply lead times accompanied by uncertainties in demand and supply of perishable produce. These challenges generate a need for proper agri logistics management system. In this paper, we present an integrated modelling approach for the distribution and production of agricultural products.

Though the concept of logistics has been practiced since ancient times still it is one of the most challenging and dynamic factors of the supply chain system. The concept of logistics and supply chain is often used synonymously but both the concepts are the two sides of the same coin. "Logistics" deals with storage, packaging, transportation of goods on the other hand "Supply chain system" deals to coordinate different parameters of logistics (Frazzon et al., 2019) (Figure 1). Logistics management includes the various related task that is required to get the right product to the right consumer in the right condition at right time and at the right cost.

Logistics management is accompanied by the warehousing and inventory that adds value to the supply chain. But the cost of creating this value is high as the warehousing and inventory management (APS Fulfillment, 2017) in itself is a separate concept to look into that involves a high-cost factor as a major constraint.

According to the $19^{\text {th }}$ "State of Logistics Report" in 2008, United States companies spent US $\$ 1,398$ billion in logistics services in 2007. Investment in transportation in 2007, ran US $\$ 857$ billion that comprises $62 \%$ of the total logistics cost (Simantov, 2019). These statistics indicate that a huge amount of capital is invested in the transportation sector. Thus, supply chain managers and decision-makers must coordinate all the parameters efficiently and effectively to minimize the loss due to poor management among the parameters.

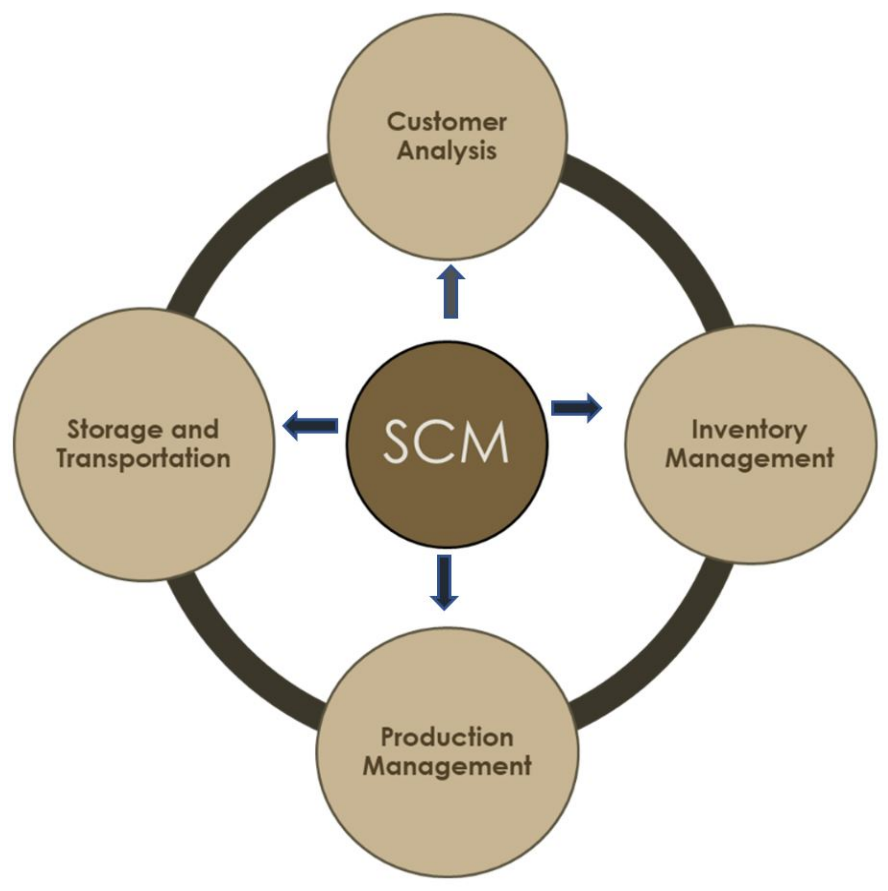

Figure 1: Parameters of supply chain Source: Authors 


\subsection{ISSUES AND CHALLENGES}

In agri- logistics one of the major issues is the perishability and product quality (He et al., 2018). More is the time length in harvesting and the time to reach the market lesser will be the price of produce. Hence time is considered as one of the major factors in the supply chain system (Ahumada and Villalobos, 2009).

To overcome the issues faced by the sectors, there is a need to take a tactical decision at the beginning of the season that includes: what to plant, how to plant, what are the operational activities involved for cultivation and what potential markets needed to target (Ahumada and Villalobos, 2011b). In particular, the formulated model will support the growers cultivating perishable crops to maximize the farm revenues.

The parameters needed to analyze were: availability of labor \& resources, demand of produce, productivity and prevailing crop price time. One of the major issues in the development and smooth functioning of the chain system is the lack of skilled labor.

In farm planning, there are several decisions that needed to be considered right from procuring seeds till it reaches the market (Nier et al., 2019). These decisions were taken at different stages as follows:

- Operational decisions: involves production management, inventory storage, distribution and transportation.

- Tactical decisions: involves land to be allocated to each crop, variety of crop to be cultivated, scheduling of pesticides and fertilizers, irrigation duration and the available mode of transportation for agricultural produce.

- Strategic planning: it aims to reach the most effective and efficient parameter of the supply chain system i.e. consumers by allocating the mandis and the market places that is easily accessible to them.

The model developed will provide an in-depth analysis of crop allocation, operational activities involved, labor required, harvesting and a conceptual model of distribution planning. The main purpose is to assist the producers in the complex supply chain management system and to supply fresh produce to consumers. The agriculture sector in India requires investment to set up an infrastructure that will reduce the crop decay and fulfil the consumer needs as and when required.

However, the emphasis has been laid on the development and improvement of agri logistics system in such a way that all the parameters accompanied by the chain, especially the farmers are benefited as they are the leading and most crucial factor of the chain. Logistics as a concept is often misinterpreted only as a function of transportation and storage. However, the fact is that "logistics" is a wide and in-depth study of the following factors (Figure 2). The increasing importance of the agri logistics is attributed mainly to the fact that the consumers need a continuous supply of perishable products.

Certain factors that affect the optimality of the system are the increased variety of agricultural products, globalization, shorter product-life, and increased regulatory complexity. All these parameters make it difficult for the system to achieve a strategic goal between what they practice and the desired dynamic customer needs (Benitez and Ferreira Lima, 2019). Thus, a conceptual framework is developed that will consider and investigate the parameters that affect the functioning of the system.

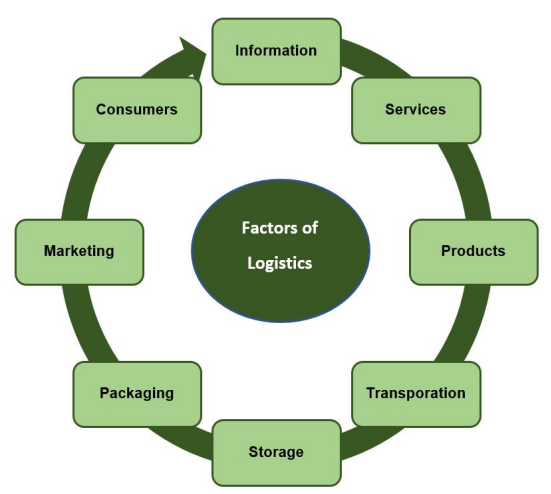

Figure 2: Different Factors of Logistics Source: Authors 
Through literature reviewed it is analyzed that farmers especially the farmers owing small areas for cultivation have been facing innumerable problems while planning their fields due to inadequate knowledge and financial constraints (Abdelaziz, 1978; Krummel and Su, 1996; Kumar, 1989; Matanga and Mariño, 1979; Ranade, 1980; Warrick and Gardner, 1983; Yang et al., 1996). The root cause of these challenges is the lack of operational and managerial decisions taken while farm planning. According to the World Bank, one of the reasons that inhibit the growth of the sector is the lack of agricultural extension services that includes postharvest decisions such as transportation network, packaging, storage, and inaccessibility of markets and mandis. Hence, there is a need to streamline all the decisions of agri supply chain (Figure 3).

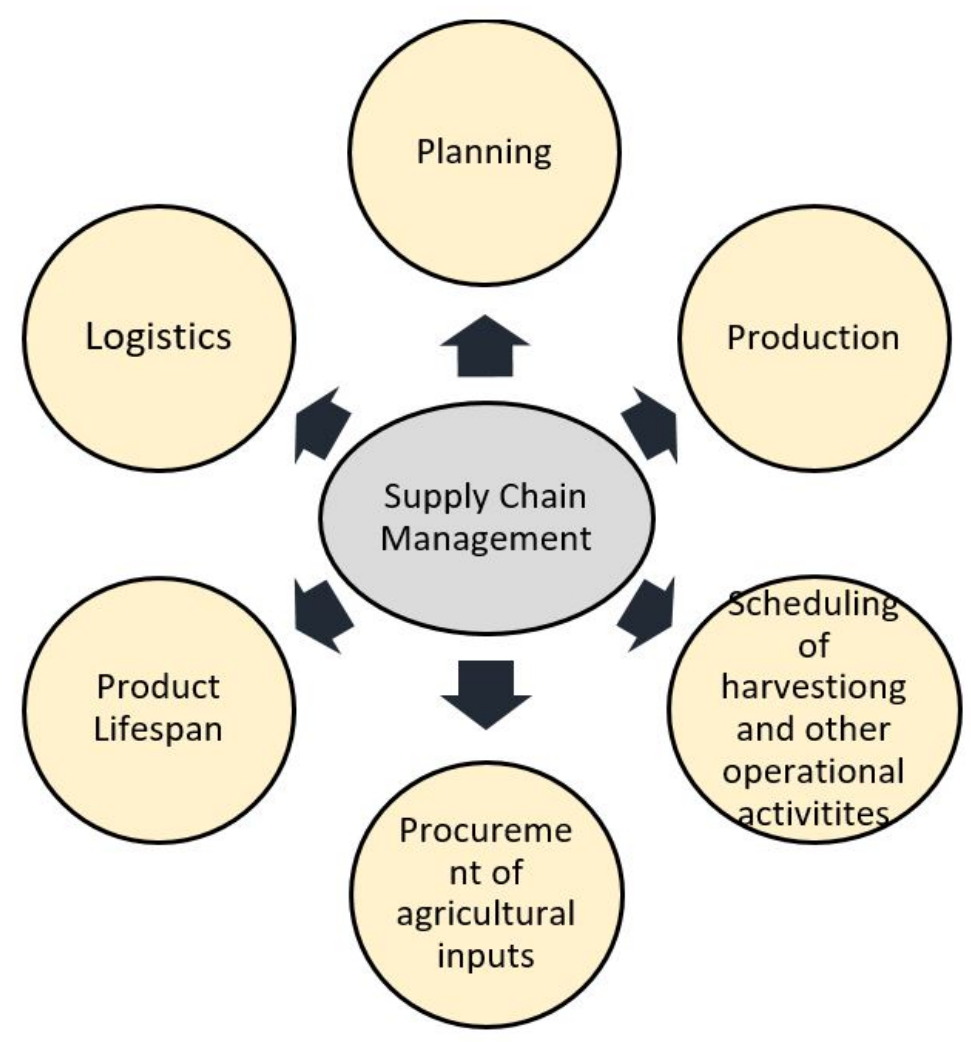

Figure 3: Decisions of Supply Chain Source: Authors

\subsection{WAREHOUSE MANAGEMENT IN INDIA}

The agriculture sector in India is one of the major contributors to its economic growth. Due to its agricultural diversity, topography, and production of agri- products it has made a country of "supply-driven" to that "market-driven". An efficient agri-supply chain system not only reduces the post-harvest losses but also makes it easy to access the nearby marketplaces. The major benefits of the supply chain especially, cold storages are to overcome the fluctuations in the market price of the product that will occur due to crop failure, low production and so on. Hence, the main focus of the Indian Government is to develop more storage infrastructures and cold storage facilities to prevent these fluctuations and prices of agricultural products. Table 1 shows the organizations along with their storage capacity. In recent years, with the increase in demand for the logistics management private sector is also investing in logistics.

The total warehouse capacity of India is around 91 million metric tonnes. However, government agencies use $66 \%$ (60 million metric tonnes) of total available agricultural storage capacity which includes 23 million metric tonnes of hired capacity. Table 2 indicates state wise storage owned by $\mathrm{FCl}$. 
Table 1: Capacity of Warehouses Owned by Government and Private Sector (India, 2015)

\begin{tabular}{clc}
\hline Sr.No. & \multicolumn{1}{c}{ Organization } & $\begin{array}{c}\text { Storage capacity in } \\
\text { (million tonnes) }\end{array}$ \\
\hline 1. & Food Corporation of India (FCI) & 36.25 \\
\hline 2. & Central Warehousing Corporation (CWC) & 10.14 \\
\hline 3. & State Warehousing Corporation (SWC) and State Agencies & 39.31 \\
\hline 4. & Cooperative Sector & 15.07 \\
\hline 5. & Private Sector & 57.75 \\
\hline & Total & $\mathbf{1 5 8 . 5 2}$ \\
\hline
\end{tabular}

Source: Government of India Department of Food \& Public Distribution New Delhi (India, 2015)

Annually, around $30-40 \%$ of the horticulture produce gets wasted due to inadequate storage and transportation network. At present, the country requires 130-140 metric tonnes of space for the storage of food grains, oilseeds, and other cash crops. The post-harvest management of agricultural produce is one of the major sectors to look into and it provides an opportunity for the private sector to invest in this aspect of the supply chain system and make it a profitable sector. The reason behind the increase in post-harvest loss is the fragmented, uneven distribution of warehouses, location \& infrastructure of warehouses, poor handling of the agri-products (Bureau, 2012).

According to the World Bank Report, the Indian logistics supply chain has improved manifolds. India acquires 35th position in international supply chain efficiency called Logistics Performance Index in 2016. Improvement and advancement in the logistics sector not only boost programs such as "Make in India" but enables India to be a part of the International Supply Chain system (Bhuyan, 2016).

Table 2 : State-wise average storage capacity owned by FCl (Food Corporation of India, 2019) (in lakh tonnes)

\begin{tabular}{cccc}
\hline Sr. No. & States & Total owned by FCl & Total capacity hired by FCI \\
\hline $\mathbf{1 .}$ & Bihar & 3.66 & 6.31 \\
\hline $\mathbf{2 .}$ & Jharkhand & 0.67 & 3.80 \\
\hline $\mathbf{3 .}$ & Orissa & 3.12 & 2.25 \\
$\mathbf{4 .}$ & West Bengal & 8.40 & 1.06 \\
\hline $\mathbf{5 .}$ & Sikkim & 0.10 & 0.01 \\
\hline $\mathbf{6 .}$ & Assam & 3.00 & 1.00 \\
\hline $\mathbf{7 .}$ & Arunachal & 0.28 & 0.02 \\
\hline $\mathbf{8 .}$ & Meghalaya & 0.13 & 0.09 \\
\hline $\mathbf{9 .}$ & Mizoram & 0.25 & 0.00 \\
\hline $\mathbf{1 0 .}$ & Tripura & 0.36 & 0.08 \\
\hline $\mathbf{1 1 .}$ & Manipur & 0.28 & 0.04 \\
\hline $\mathbf{1 2 .}$ & Nagaland & 0.33 & 0.10 \\
\hline $\mathbf{1 3 .}$ & Delhi & 3.36 & 0.00 \\
\hline $\mathbf{1 4 .}$ & Haryana & 7.68 & 49.30 \\
\hline $\mathbf{1 5 .}$ & Arunachal Pradesh & 0.19 & 0.34 \\
\hline $\mathbf{1 6 .}$ & Jammu \& Kashmir & 1.03 & 1.32 \\
$\mathbf{1 7 .}$ & Punjab & 22.24 & 88.50 \\
\hline $\mathbf{1 8 .}$ & Chandigarh & 0.00 & 0.064 \\
\hline $\mathbf{1 9 .}$ & Rajasthan & 7.20 & 10.34 \\
\hline $\mathbf{2 0 .}$ & Uttar Pradesh & 14.9 & 39.51 \\
\hline $\mathbf{2 1 .}$ & Uttarakhand & 0.00 & 0.98 \\
\hline
\end{tabular}


Table 2: Continued...

\begin{tabular}{cccc}
\hline Sr. No. & States & Total owned by FCl & Total capacity hired by FCl \\
\hline $\mathbf{2 2 .}$ & Andhra Pradesh & 7.29 & 6.14 \\
\hline $\mathbf{2 3 .}$ & Andaman \& Nicobar & 0.07 & 0.00 \\
\hline $\mathbf{2 4 .}$ & Telangana & 5.37 & 10.0 \\
\hline $\mathbf{2 5 .}$ & Kerala & 5.29 & 0.12 \\
\hline $\mathbf{2 6 .}$ & Karnataka & 3.81 & 4.44 \\
$\mathbf{2 7 .}$ & Tamil Nadu & 5.80 & 6.32 \\
\hline $\mathbf{2 8 .}$ & Puducherry & 0.44 & 0.83 \\
\hline $\mathbf{2 9 .}$ & Gujarat & 4.05 & 2.13 \\
\hline 30. & Maharashtra & 8.68 & 10.47 \\
\hline 31. & Goa & 0.15 & 0.05 \\
\hline 32. & Madhya Pradesh & 3.37 & 4.35 \\
\hline 33. & Chhattisgarh & 5.17 & 2.89 \\
\hline
\end{tabular}

Source: (Food Corporation of India, 2019. CapacityJune19.pdf)

Table 3: Month-wise food grains procured by FCl (in lakh metric tonnes)

\begin{tabular}{ccccccccccccc}
\hline Year & Jan & Feb & March & April & May & June & July & Aug & Sep & Oct & Nov & Dec \\
\hline $\mathbf{2 0 1 6}$ & 364.77 & 365.74 & 362.89 & 366.99 & 527.65 & 534.29 & 495.95 & 455.96 & 407.76 & 358.02 & 313.62 & 275.55 \\
\hline $\mathbf{2 0 1 7}$ & 272.22 & 285.80 & 298.36 & 311.40 & 524.69 & 555.40 & 533.19 & 499.77 & 459.98 & 421.73 & 378.77 & 347.91 \\
\hline $\mathbf{2 0 1 8}$ & 357.68 & 374.40 & 384.34 & 381.04 & 607.07 & 680.25 & 650.53 & 627.13 & - & - & - & - \\
\hline
\end{tabular}

Source: Food Cooperation Of India (2018)

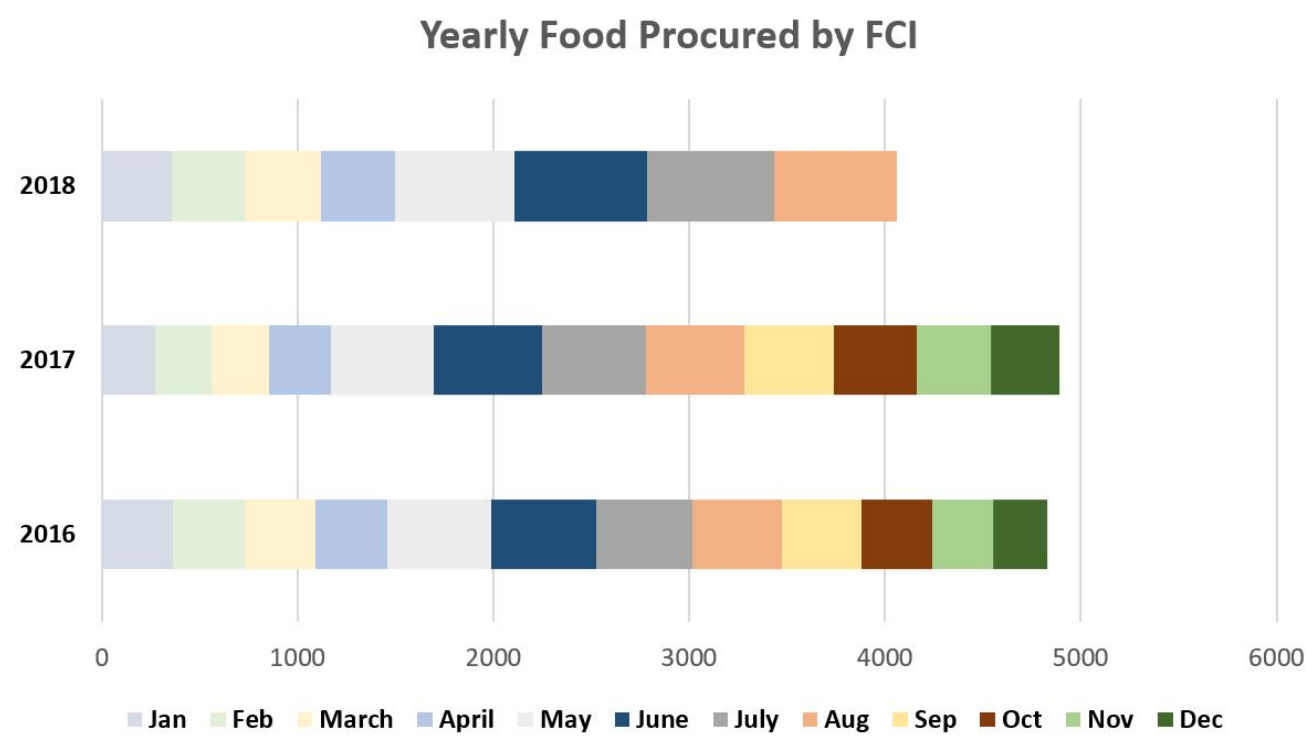

Figure 4: Food procured by Food Corporation of India (FCI)

Table 3 indicates the month-wise food grain stored by $\mathrm{FCl}$. As per the reports of the Union Ministry of Agriculture and Farmer's welfare, India would have a bumper production of food grains. The latest historic figure for production is 283 million metric tonnes. $\mathrm{FCl}$ storage houses are flooded with grains and there is a large number of losses due to such a large quantity of harvested grains. Nafed and Food Corporation of India (FCI), in the year 2018-19 has procured nearly 38 lakh tonnes of oilseeds and pulses Figure 4. As per the records, in Rabi \& Kharif season quantity of food grains purchased in 2018-19, 19.7 lakh tonnes, and 18 lakh tonnes 
respectively. Current storage capacity in the country is 877.37 lakh tonnes (Business Standard, 2018).

Table 4: Food production in India in 2018-19

\begin{tabular}{|c|c|c|c|}
\hline Sr.no. & Crops & Year & $\begin{array}{c}\text { Production (million } \\
\text { tonnes) }\end{array}$ \\
\hline \multirow{2}{*}{1.} & \multirow{2}{*}{ Food grains } & $2018-19$ & 281.37 \\
\hline & & $2017-18$ & 284.83 \\
\hline \multirow{2}{*}{2.} & \multirow{2}{*}{ Oilseeds } & 2018-19 & 31.50 \\
\hline & & $2017-18$ & 31.31 \\
\hline \multirow{2}{*}{3.} & \multirow{2}{*}{ Sugarcane } & 2018-19 & 380.83 \\
\hline & & $2017-18$ & 376.90 \\
\hline
\end{tabular}

Source: Department of Agriculture, Cooperation \& Farmers Welfare (India, 2018)

As per the 2nd Advance Estimate for 2018-19 (Table 4), total food grain production in 2018-19 is reduced by 3.46 million tonnes than in the year 2017-18. However average food grain production has increased by 15.63 million tonnes than the previous 5 years (2013-14 to 2017-18). Total oilseeds production in the country is increased by 1.85 million tonnes than the average oilseeds production. Similarly, the production of sugarcane has increased to about 31.05 million tonnes than the average sugarcane production over the last five years.

The reports indicate that crop production in the country increases every year. Thus, there is a need to improve infrastructure to prevent post-harvest losses. As per the records in India, $20 \%$ (Bureau et al., 2019) of food-grains were spoiled annually due to rodent attack, pilferage, poor- handling of agri-produce during transportation and inappropriate storage facilities.

In the agriculture sector, farmers are the main component of the supply chain management system especially those that cultivate perishable products. Fluctuations in climatic conditions had impacted the product perishability and hence farms output. Further, they have to face the change in market conditions due to varying consumer demand. It is believed that the consolidation of retailers will continue in near the future results in the smooth functioning of the Agri supply chain management system. The developed model will help producers who access directly to the market by coordinating with each parameter of the supply chain depending on their requirements.

According to the Ministry of Food and Public Distribution, agencies responsible for storage has a storage capacity of 85.15 million tonnes out of which only 72.45 million tonnes capacity of warehouses are covered. One major issue in storage is that these storage places does not guarantee the "first-in and first-out" principle of agri-produce. Consequently, the stock stored in the early phase has more chances of getting spoilt (Subramani, 2019).

\section{LITERATURE REVIEW}

Traditionally, planning a farm involves various decisions such as crop allocation, operated mechanized system, harvest scheduling, and many other factors. Most of the models develop focusses on traditional crops, with a smaller number of farm model that aims at developing a model that considers a perishable crop. (Ahumada and Villalobos, 2011b) proposed an operational farm model that gives an insight into the fresh produce industry. The developed model helps the decision-makers to maximize farm revenues. The idea of the paper is generated from the fact that the profitability of the producer depends on short-term planning in the harvest season. This will provide an insight into the kind of decision variables is to consider that will maintain the product perishability (short-term decisions) and optimizes the farm returns.

Most of the existing literature focuses on traditional crops, a smaller number of experts have laid attention to perishable products from the view of tactical modeling. Since labor is 
one of the crucial factors in agriculture planning thus one of the factors that need an in-depth analysis is the availability of labor especially in the case of perishable crops (Zhang and Wilhelm, 2011).

(Ferrer et al., 2008) developed an operational model for harvesting, which includes a tactical decision such as the amount of produce to be harvested per period, the mode of transportation to be availed for transporting agricultural produce to inventories and then scheduling of packing and processing plants. Mixed-Integer Programming model is developed for optimally scheduling of the harvesting, labor, and transportation routing operations of wine grapes. The cost of harvesting and the rate of deterioration rate of wine grapes were taken under consideration. The main contribution of the paper is the inclusion of the decay rate of grapes in the objective function of the model. Paper overviews a decay period of perishable crops.

(Rong et al., 2011) developed a model to control the food quality throughout the supply chain system. The model will consider the quality of agricultural produce as one of the major decision-making variables in production and distribution planning.

Hence, from reviewed literature two of the most significant parameters in supply chain management of perishable crop that can be incorporated in one mathematical model is the lead time decay and type of transportation network to be considered depending upon the perishable nature of the crop (Blackburn and Scudder, 2009).

Supply chain management is considered as a system that integrates all the factors and provides a link to associate, parameters of chain for the smooth inflow of agricultural produce (Moazzam et al., 2012)

In the supply chain management system, the supply of perishable products is a critical issue due to its short life span and high decay coefficient parameter. (Boudahri et al., 2013) deals with the planning and management of poultry products. The main purpose of the study is to redesign the existing supply chain to optimize distribution planning.

Di et al. (2011) consider a distribution network design where the decision has to consider regarding the allocation of sites for the distribution of the perishable agricultural product. The paper aims to minimize the location, inventory, transportation, and distribution cost. The decision-makers also consider the decay loss in transportation. (Catalá et al., 2013) formulate an optimal model for restructuring the production of apple and pears. The main focus is to optimally plan the investment of the farm, maximizing the farm's profit by dynamically allocating the crops in a given time horizon based on available financial constraints.

Globalization and rapid change in population have raised the demand for agri-food products. However, the variations in climatic conditions, product perishability, change in demand of consumers poses a great challenge for the development of effective and efficient supply chain system that caters the need of all the sectors of the chain.

With the increase in demand for agricultural produce, proper management among all the parameters of agriculture including production, harvesting, transportation, storing, packaging, marketing has become a necessity. (Olena and Maryna, 2016) focusses on the problem faced in the agricultural logistics system in Ukraine. Market institutions play a crucial role in coordinating a link among these parameters. The results of the study reveal that the implementation of logistics in the Agri supply chain will allow the following:

- Optimizing the flow between the different parameters of the sector.

- Optimization and allocation of resources

- Coordinating transportation networks

- Inventory and storehouse management

- The continuous flow of agri-products among all the parameters

Hence, to provide coordination \& link all the factors of the supply chain system a conceptual model is developed that enables to cope up with the problems faced in the agriculture sector.

Further, (Mogale et al., 2017) for the distribution of fresh vegetables, proposed a vehicle routing algorithm. Perishability as a critical concept was developed by using an algorithm for 
the distribution of fresh vegetables. (Osvald and Stirn, 2008) proposed a food grain supply chain problem faced in India to satisfy the demand of the deficit Indian states. A Mixed Integer Non-Linear Programming model is formulated that aims to minimize the overall operational cost involved in storage and shipment. Along with the type of transportation network involved in a chain some other parameters such as seasonal procurement of agri-produce, storage, and vehicle capacity and satisfying the demand of consumers were taken under consideration to study.

(Onggo et al., 2019) modelled a multi-period inventory routing problem by applying Mixed-Integer Programming as a tool.

Thus, many researchers (Ahumada \& Villalobos, 2011) developed conceptual and mathematical model that aims to minimize the post-harvest losses. The further sections of the paper discuss about the methodology followed by the mathematical and conceptual framework leading toward the discussion.

\section{METHODOLOGY}

To analyze the functioning of the logistics system a hypothetical farm in which farmers cultivate tomatoes, bell peppers, and cucumbers (perishable products) was considered. However, fresh agricultural producers have to make several decisions regarding crop allocation (it is a crucial aspect for the perishable produce) and planting. Planting decisions include the selection of best variety, area to be cultivated under each type of crop, and timeperiod to plant a particular variety. Most of the time all these decisions were made based on the demand and expected price of the product in the market. From a survey conducted with farmers it is observed that nowadays, to prevent the crop from varying climatic conditions farmers prefer to cultivate perishable products especially cucumber, chilies and bell peppers in green houses. Because of this, the risk of crop failure is minimized and production is increased. Operational activities time horizon, to cultivate the field with tomatoes, bell peppers, and cucumbers is listed in Table 5.

As per the planning schedule represented in Table 5, it can be evaluated that during the growing season the cultivating and harvesting activities overlap with each other. One of the reasons for this is that both these activities use a scarce resource i.e. labor. This indicates that there is a need to manage labor, particularly in peak season. The main challenge with labor planning is that the seasonal agricultural labour are limited in number, and due to a large requirement of fresh produce, labor can become one of the limited and restricted resources for planning.

Table 5: Operational activities in cultivating tomatoes, bell peppers and cucumbers

\begin{tabular}{|c|c|c|c|c|c|c|c|c|c|c|c|c|c|c|c|c|c|}
\hline \multirow{2}{*}{ Crop variables } & \multirow{2}{*}{ hectares } & \multicolumn{4}{|c|}{ Sep } & \multicolumn{4}{|c|}{ Oct } & \multicolumn{4}{|c|}{ Nov. } & \multicolumn{4}{|c|}{ Dec. } \\
\hline & & 1 & 2 & 3 & 4 & 1 & 2 & 3 & 4 & 1 & 2 & 3 & 4 & 1 & 2 & 3 & 4 \\
\hline \multirow{2}{*}{ Tomatoes } & \multirow{2}{*}{50} & & & * & * & * & & & & & $\$$ & $\$$ & $\$$ & $\$$ & $\$$ & $\$$ & $\$$ \\
\hline & & & & & & \# & \# & \# & \# & \# & \# & \# & \# & \# & \# & & \\
\hline \multirow{2}{*}{ Cucumbers } & \multirow{2}{*}{30} & * & * & & $\$$ & $\$$ & $\$$ & $\$$ & $\$$ & & & & & & & & \\
\hline & & & $\#$ & $\#$ & $\#$ & & & & & & & & & & & & \\
\hline \multirow{3}{*}{ Bell peppers } & \multirow{2}{*}{20} & * & & & & & & & & & $\$$ & $\$$ & $\$$ & $\$$ & $\$$ & $\$$ & $\$$ \\
\hline & & & $\#$ & $\#$ & $\#$ & \# & \# & \# & \# & \# & \# & \# & \# & & & & \\
\hline & & * & & & ting & Crop & & \# & & & vatic & & $\$$ & & & vest & \\
\hline
\end{tabular}

To overcome this challenge the developed model will consider the availability of both seasonal and hired farm laborers. The difference among two is that seasonal labor is contracted for a particular season whereas, hired laborers were required only for a particular duration of crop planning such as at the time of harvesting. The need for labor is constrained by financial condition and labour availability in a season. Linear Programming as a tool is 
applied to get optimized output of the model. Figure 5 represents the methodology adopted for analysis.

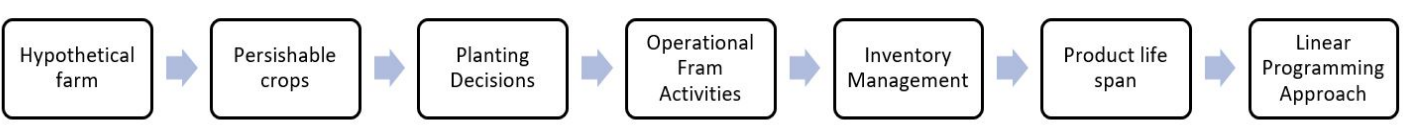

Figure 5: Methodology for supply chain management of perishable crop Source: Authors

\subsection{CONSTRAINTS IN PLANNING A PERISHABLE CROP}

One of the major differences between the traditional cropping scenario and the model proposed, is the management of product decay and its perishability. The developed model will take care of the product perishability in two ways: first by restricting the maximum storage time for the produce. For example, in the case of tomatoes, the life of it is dependent on the shell color that determines the freshness.

Constraints that lead to diminishing the life span of the product are always accompanied by production-distribution plan model depending on the type of crop considered. However, these constraints did not affect the perishability of products within a limited time horizon once it is harvested. But after a specific period, it leads to certain odd decisions such as using railways instead of roadways to deliver the product that leads to an increase in farm cost.

To avoid product decay there is a judicious need for inventory management. Further, it is observed that with the increase in transportation time there is a reduction in product market price due to its diminished quality and freshness. Thus, a decay function (Figure 6) is proposed by (Osvald and Stirn, 2008) for peppers that show the relation of how the product life decays with the increase in transportation length.

Figure 6 shows the decay function for a perishable crop, indicating the fall in product price at a constant rate over some time.

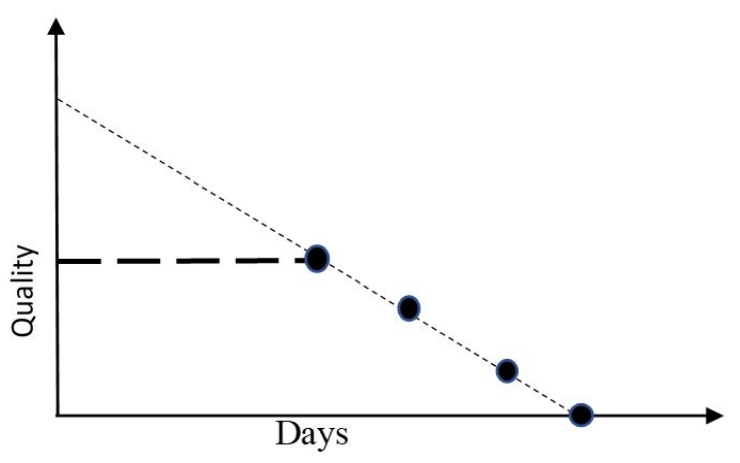

Figure 6: Indicates the product decay with the increase in transportation length

\subsection{MODEL ASSUMPTIONS}

For the formulation several assumptions were made:

- Farmers have basic infrastructural facilities such as land, water, seeds, fertilizers, etc.

- Allocation of crops and the operational activities involved for production are pre-decided.

Decision parameters that were looked into while formulating a supply chain management model include the decision variables such as land allocation for each type of crop, time of sowing \& harvesting, labour planning, mode of transportation (depending on the type of cultivated crop) availability of water resources and another operational activity to minimize the farm expenses. 
Unlike the farmers who cultivate cereals and grains, growers of perishable agricultural produce, have certain different constraints as compared to other farmers cultivating grains and cereals. To maintain the perishability of the product they need to access proper inventory.

Farmers play a significant role in the supply chain as they are the main drives that link production and distribution. As a result, some producers leave the distribution of their products to the intermediaries while others handle the logistics sector on their own to reduce cost. Figure 7 represents the systematic in-flow among different parameters of the chains.

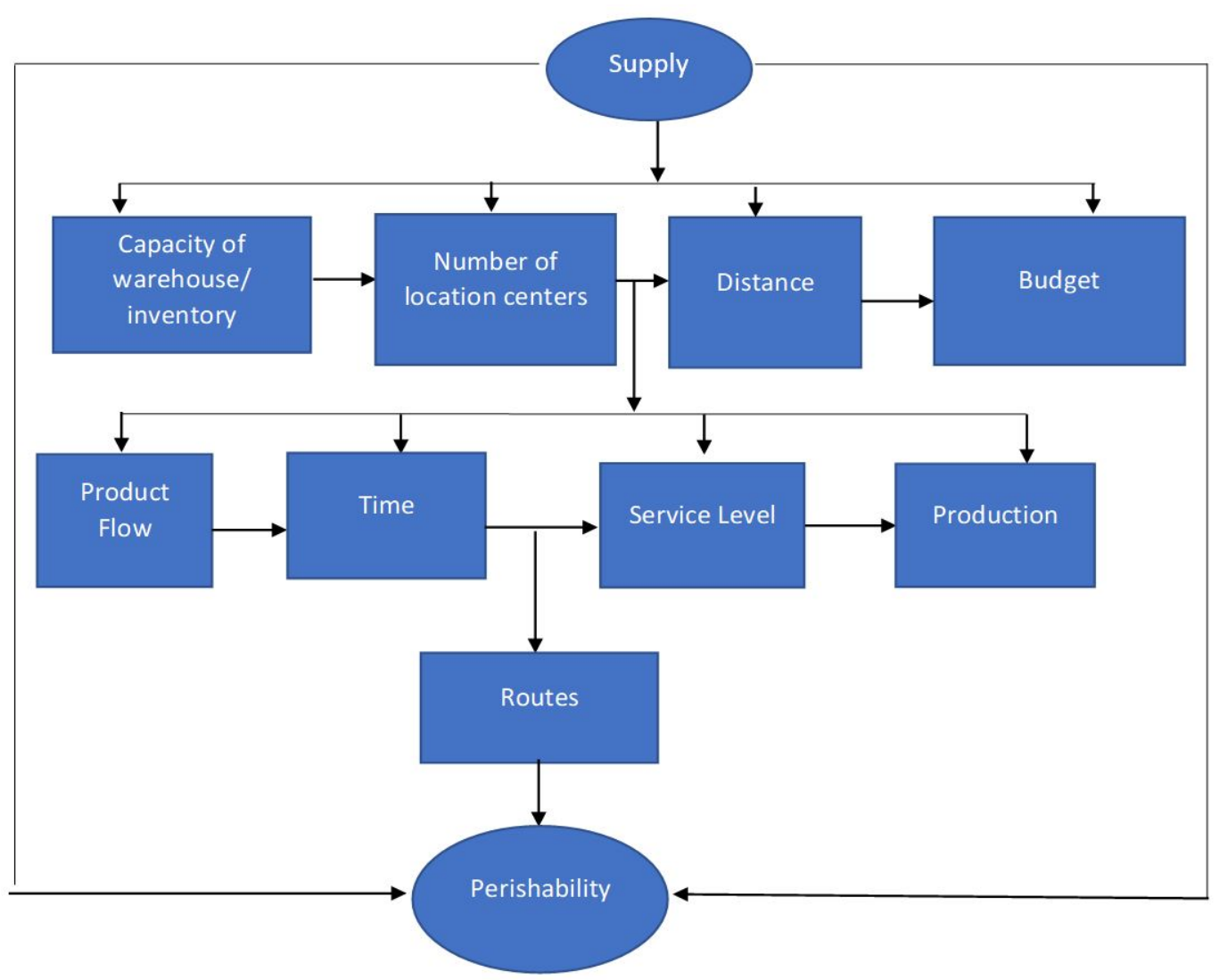

Figure 7: Systematic Framework of Agri-Supply Chain Source: Authors

Logistics initiate as soon as the crop is harvested at the farm level. Depending on the quality, quantity, and market price of the harvested crop the price of product, the granaries, and the agricultural warehouses were identified by the growers to store their crops. Most of the farmers due to financial constraints prefer to store the crop in their fields only. Thus, the budget is one of the significant components of the supply chain system. Since the majority of the perishable crops are being transported from one place to another thus, time quality of service, continuous flow of products, and routes to be taken up by the transporters are some of the crucial challenging parameters of the supply chain system. Figure 6 shows the systematic framework of agri-supply chain.

According to the model (Figure 8) farmers have several locations to sell their farm produce such as nearby markets and mandis but all these locations must be allocated nearby farms so that the cost involved in the transportation of goods is minimized. These locations could be different in terms of their geographical position and infrastructure. Farmers can adopt different types of packaging facilities, warehouses and, distribution centers depending on the crop and their financial and economic conditions. Most of the small farmers were not able to access all these facilities due to capital constraints. 
Hence, there is a need to make the Agri supply chain system accessible and adaptable for the farmers by optimizing production and distribution costs.

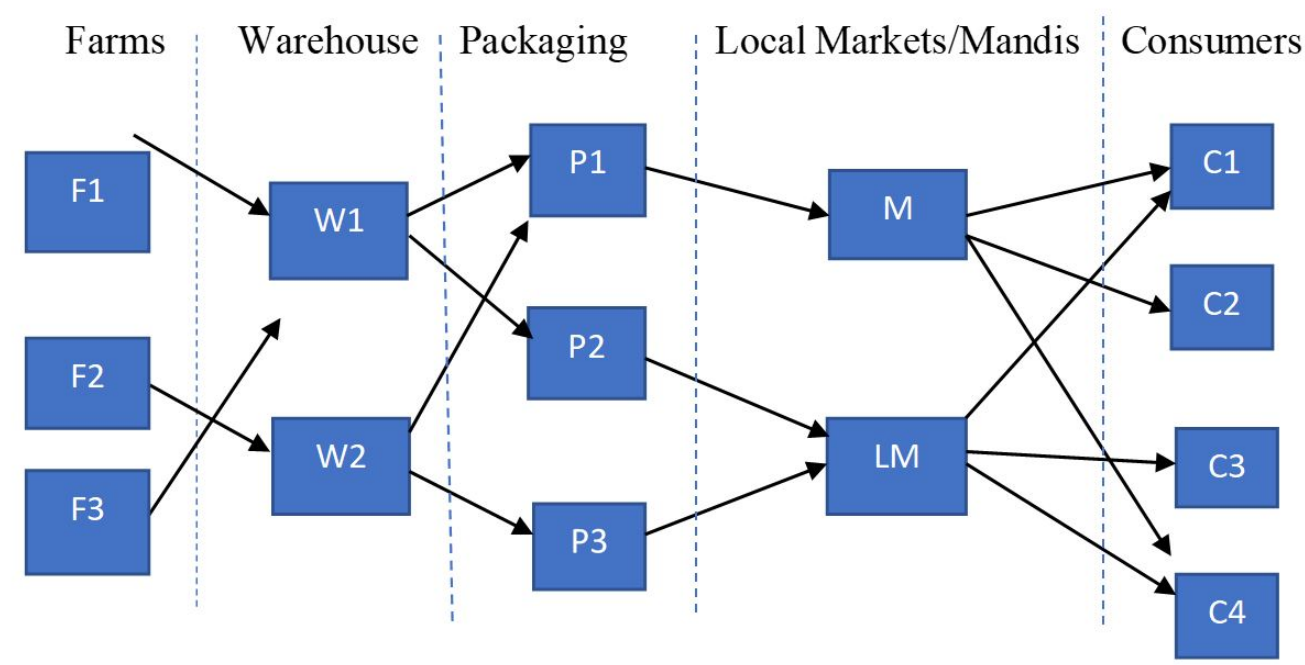

Figure 8: Systematic flow of agricultural produce among different parameters of SCM Source: Author

According to Figure 7 different farms (F1, F2 \& F3) at different locations were considered to determine the transportation cost. These farms could be different in terms of topography, market accessibility, and availability of resources especially, labor and water. These two resources are crucial in the case of perishable agricultural products as plantation of these crops requires skilled labor and an accurate quantity of water for their cultivation. Growers have an alternative to opt for warehouses (W1 \& W2) depending upon the quantity and the type of crop cultivated. Product packaging is one of the most important \& complex components of the SCM system. Once the product gets packed it will be transported to local markets \& mandis where it is easily accessible to consumers.

\subsection{MODEL FORMULATION}

The objective of the developed framework model is to reduce farm expenses by allocating farm resources optimally. The farm revenues are obtained depending on external (such as market price fluctuation of agricultural produce) and internal conditions (such as type of crop cultivated, land allocated to each crop). In model developed decisions were assumed to take for a finite planning horizon ( $\mathrm{t}$ ). The time horizon $\mathrm{t}$ represents the product decay time period.

Constraints of the model were:

$\sum \sum G_{\text {tia }} \leq T A_{a}$

$\mathrm{G}_{\text {tia }}$ represents $\mathrm{i}^{\text {th }}$ type of crop allocated on land (a) (in hectares) in time period $t$ $\mathrm{TA}_{\mathrm{a}}$ represents the available land for crop allocation (in hectares)

$\sum \Sigma P_{t i} \cdot G_{t i a} \leq T I$

$\mathrm{P}_{\mathrm{ti}}$ represents production cost per hectare of $\mathrm{i}^{\text {th }}$ in time period $\mathrm{t}$

TI represents total investment (in Rs.) 


$$
\sum \Sigma \Sigma W_{i} \cdot G_{t i a} \leq T W
$$

$W_{i}$ represents water required by $i^{\text {th }}$ crop in time period $t$ TW represents total water available for irrigating the fields $\mathrm{X}_{\mathrm{ia}}=0$ when $\mathrm{i}^{\text {th }}$ type of crop is not cultivated in time period $\mathrm{t}(4)$ $X_{i a}=1$ when $i^{\text {th }}$ type of crop is cultivated in time period $t(5)$

$$
H_{\text {thia }}=Y_{\text {thia }} \cdot T_{\text {tia }} \cdot G_{\text {tia }}
$$

$H_{\text {thia }}$ represents harvesting of $\mathrm{i}^{\text {th }}$ crop in period $\mathrm{h}$, planted in time period $t$ allocated on land (a) (in hectares)

$\mathrm{Y}_{\text {thia }}$ represents yield (per hectare) of $\mathrm{i}^{\text {th }}$ crop planted in time period $\mathrm{t}$ and harvested in $\mathrm{h}$ time period, allocated on land (a) (in hectares)

$\mathrm{T}_{\text {tia }}$ represents area under $\mathrm{i}^{\text {th }}$ crop, allocated on land (a) (in hectare) in time period $\mathrm{t}$

$$
\sum K P_{\text {thiaf }}=H_{\text {thia }}
$$

$\mathrm{KP}_{\text {thiaf }}$ represents $\mathrm{kgs}$ of produce i allocated on area (a) (in hectare) is transported from farm to location

$$
M L_{t a}+M L_{t l} \geq \sum M P_{t i} \cdot G_{t i a}+M H_{t h i} . H_{t h i a}
$$

$\mathrm{ML}_{\mathrm{t}}$ represents no. of seasonal labor required at time period $\mathrm{t}$ for location I (labormonth/hectare)

$\mathrm{ML}_{\mathrm{t}}$ represents no. of hired labor required at time period $\mathrm{t}$ for location I (labor-month/hectare) $\mathrm{MP}_{\mathrm{ti}}$ represents number of labour required for cultivating $\mathrm{i}^{\text {th }}$ crop in time period $\mathrm{t}$ (labormonth/hectare)

$\mathrm{MH}_{\text {thi }}$ represents number of labour required for harvesting $\mathrm{i}^{\text {th }}$ crop in time period $\mathrm{t}$ (labormonth/hectare)

$$
P_{h k c f}=Q_{h k c}-D_{j}
$$

$P_{\text {hkcf }}$ represents quantity of product $k$ get packed in period $\mathrm{h}$ with color $\mathrm{c}$

Qhkc represents harvested quantity k of the vegetables with color $\mathrm{c}$ in period $\mathrm{h}$

$D_{j}$ represents the quantity of decayed product $j$

$$
\sum H L_{k} \cdot P_{h k c f} \leq H F_{h f}
$$

$H L_{k}$ represents the labor needed for packaging a product $k$

$P_{\text {hkcf }}$ represents quantity of product $k$ get packed in period $h$ with color $\mathrm{c}$

$\mathrm{HF}_{\mathrm{hf}}$ represents the operator hours allocated at facility $\mathrm{f}$ and harvest time $\mathrm{h}$

Constrains (1)- (5) represents the limiting (land, water, area allocated under each crop) resources availability at farm. However, these resources are fixed resources. Moreover, constraints (1), (2) \& (3) assured that the resources used by the solution will not exceed the total available land, capital and water resources. Constraint (4) \& (5) represents upper and lower bound for planting a crop in particular season. This decision depends on the market 
price of the product planted as the previous season price of the product will determine whether the same type of crop would be cultivated or not. (6) represents that the harvested quantity of produce is equal to that of planted one. Since crops undergo multiple harvesting $Y_{\text {thia }}$ represents the yield of $i$ th crop harvested in period $h$ cultivated on area (a) (in hectare). Equation 7 shows the quantity of produce get transported to facility of after packaging. Constraint (8) represents the availability of labors at planting harvesting time period. Equation 9 represents the quantity of the product that will transported to warehouses or nearby markets. Constraint (10) represents the operational activities and hours involved in packaging of product.

\section{RESULTS AND MODEL VALIDATION}

To test the formulated model, several crop combinations, cropping patterns and spatial distribution of crops were studied. To get the results LINGO 18.0 Software is used. The factors evaluated include number of crops (C), product-decay time period (T), crop production period $(P P)$, harvest period $(H)$, consumers $(\mathrm{I})$, location $(L)$, Plants $(P)$ warehouses $(W), D C$ 's $(D)$, product (K), Transportation modes (TM)

Table 6: Results of Experiments

\begin{tabular}{|c|c|c|c|c|c|c|c|c|c|c|c|c|c|c|c|c|}
\hline SC & $\mathbf{T}$ & PP & $\mathbf{H}$ & I & $\mathbf{L}$ & $\mathbf{P}$ & V & D & K & TM & Row & Col & Ion & inary & Gap & Time \\
\hline 6 & 40 & 6 & 18 & 4 & 2 & 2 & 2 & 2 & 8 & 3 & 25,545 & 71,243 & 235,455 & 12,504 & $0.0 \%$ & 45 \\
\hline 6 & 40 & 6 & 20 & 100 & 2 & 2 & 2 & 12 & 8 & 1 & 34 & 3,845 & 30 & 992 & $.0 \%$ & 36 \\
\hline 6 & 60 & 15 & 22 & 4 & 2 & 2 & 2 & 2 & 8 & 3 & 84 & 84 & 56 & 312 & $3 \%$ & 78 \\
\hline 6 & 60 & 15 & 22 & 100 & 2 & 2 & 2 & 12 & 8 & 1 & 25,545 & 136,452 & 356,300 & 60,407 & $0.4 \%$ & 3600 \\
\hline 30 & 60 & 15 & 22 & 4 & 2 & 2 & 2 & 2 & 8 & 3 & 22 & 50 & 525 & 712 & $0.4 \%$ & 3500 \\
\hline 30 & 60 & 15 & 22 & 100 & 2 & 2 & $z$ & 12 & 8 & 1 & 29,168 & 25,136 & 412,897 & 61,456 & $0.0 \%$ & 3392 \\
\hline
\end{tabular}

Model results were illustrated in Table 6 in terms of CPU seconds (Time) and optimality gap. Other sections of the table include the number of rows (Row), number of variables (Col), the non-zero coefficient in matrix (Non) and number of binary variables (Binary). A large number of binary variables is the main contributor to total time observed.

However, the model complexity would be reduced if the resolution of decision variables is changed from weeks to days, increasing in the number of planting and harvesting variables.

For model validation, a layout is prepared for planting, harvesting and distribution of the crops from a hypothetical producer. The model formulated reviews the entire growing period, from planting till harvesting. It is assumed that the grower cultivates bell peppers, cucumbers and tomatoes.

To estimate the productivity of crops we use secondary data provided by logistics and service providers. The major decision is to satisfy consumer demand, which is presented by managing the time variable between planting and harvesting. Thus, to fulfil the model requirement we use the matrix developed by (Comisón para la Investigación y Defensa de las Hortalizas de Sinaloa, 2020), the results for one of the cultivated variety of tomatoes are shown in table 7.

The developed model will be elaborated by associating different crop combinations, crop allocations, harvesting, and other operational activities. The complexity of the model is associated with planting and a variety of crop cultivated. Thus, the model developed will consider all the decisions that will affect the cultivation activities evolved. However, the main focus of the model developed is the distribution decision, which can be plotted as a continuous flow of commodity among all the parameters of the supply chain system. A major decision in the agriculture sector is the timing of planting and harvesting of crops to meet consumer requirements. 
Table 7: Plant and harvest matrix for Tomatoes

\begin{tabular}{|c|c|c|c|c|c|c|c|c|c|c|c|c|c|c|c|c|c|}
\hline Week & 12 & 13 & 14 & 15 & 16 & 17 & 18 & 19 & 20 & 21 & 22 & 23 & 24 & 25 & 26 & 27 & Total \\
\hline 1 & 0.01 & 0.09 & 0.18 & 0.18 & 0.19 & 0.03 & 0.11 & 0.04 & 0.06 & 0.02 & 0.09 & & & & & & 1.0 \\
\hline 2 & & 0.09 & 0.18 & 0.18 & 0.19 & 0.03 & 0.11 & 0.04 & 0.06 & 0.02 & 0.09 & 0.09 & & & & & 1.0 \\
\hline 3 & & & 0.09 & 0.18 & 0.18 & 0.19 & 0.03 & 0.11 & 0.04 & 0.06 & 0.02 & 0.09 & & & & & 1.0 \\
\hline 4 & & & & 0.09 & 0.18 & 0.18 & 0.19 & 0.03 & 0.11 & 0.04 & 0.06 & 0.02 & 0.09 & & & & 1.0 \\
\hline 5 & & & & & 0.09 & 0.18 & 0.18 & 0.19 & 0.03 & 0.11 & 0.04 & 0.06 & 0.02 & 0.09 & & & 1.0 \\
\hline 6 & & & & & & & 0.12 & 0.07 & 0.15 & 0.22 & 0.17 & 0.02 & 0.08 & 0.05 & 0.07 & 0.05 & 1.0 \\
\hline
\end{tabular}

Two locations for cultivation for the proposed supply chain is considered including two packaging units, two warehouses, three customers and two distribution centers. The maximum storage time is estimated with the previously published reports (Welby and McGregor, 2004). For tomatoes and cucumber, the decay time duration is a week and for a bell pepper it is for two weeks.

The recommended planting plan is presented in Table 8. The table illustrates the crop selection, timing and area to be allocated to each cultivated crop. Variety $A$ of bell pepper $(A B P)$, variety $B$ and $C$ of tomatoes (TB \& TC) and variety $A$ of cucumber (CA) were selected for cultivation. Results indicate that in the first week farmer should cultivate 12 hectares of land with variety $A$ of bell peppers and the activities for different week was planned (Table 8). Result of the model indicate that if growers were able to sell their product directly to the consumers than their revenues show a rise of $25 \%$. The results are very promising, even though the deterioration period and risk factor of crop handling is considered.

Table 8: Crop Selection and Cultivation Period

\begin{tabular}{|c|c|c|c|c|c|}
\hline \multirow{2}{*}{ Week } & \multicolumn{4}{|c|}{ Crop Selected } & \multirow{2}{*}{ Total Week } \\
\hline & ABP & TB & TC & $\mathrm{CA}$ & \\
\hline 1 & 12 & - & - & - & 12 \\
\hline 3 & - & 16 & - & - & 16 \\
\hline 4 & - & 12 & 16 & - & 28 \\
\hline 7 & - & - & - & 25 & 25 \\
\hline 8 & - & - & - & 12 & 12 \\
\hline 11 & 12 & - & - & - & 12 \\
\hline 13 & 8 & - & 6 & - & 14 \\
\hline 16 & - & 9 & - & - & 9 \\
\hline 18 & - & - & 10 & 3 & 12 \\
\hline Total Crop & 32 & 37 & 32 & 40 & 140 \\
\hline
\end{tabular}

\section{DISCUSSION AND CONCLUSION}

The complexity of the model depends on the type of crop cultivated and the capital invested by the growers. By interviewing the farmers, it is observed that farmers with small landholdings (Scare et al., 2019) did not prefer to invest in storage facilities due to a lack of financial constraints. In the case of buffer production, they make small storage at their farms. They sell the agricultural produce to the nearby market places depending upon the quantity and quality of production. Generally, because of low capital investments, farmers have to face a loss due to sudden climatic variations. The crop kept in the field gets deteriorated by the sudden change in weather.

Farmers owning a large piece of land avail inventory facilities to keep their agricultural produce. By interviewing the farmer's, we came to know that the type of storage and packaging of the agricultural products depends on the nature of produce. In the case of cultivation of 
grains and cereals, the complexities associated with storage, packaging, and transportation is quite less as compared to that with the perishable crop (due to their short life span). Generally, gunny bags were used for the storage of food crops such as rice, wheat, millets, pulses but for perishable crops such as fruits, spices special type of packaging is required that make the produce fresh for a longer time period till it reaches to market. In India, food grains are normally kept in silos and perishable crops were stored in cold storages.

Another major issue in the agri supply chain is the continuous and multi-flow of agricultural produce. It is often observed that there is an irregularity in the flow of agriproduced is caused due to poor harvest techniques or a sudden increase in demand for a particular product caused by the sudden change in climatic conditions.

The developed model thus results in, planning a farm model from cultivation till harvesting. To analyze the different parameters affecting the decision variables a hypothetical farm planting tomatoes, cucumber, and bell peppers are taken under consideration to determine the operational cost involved in logistics management of perishable crops. Only the perishable crops (Schotzko and Hinson, 2000) were considered to study so that the complexities and the constraints associated with the packaging, storage, and harvesting of these crops will be observed and analyzed. By discussion with farmers, it is observed that the type of transportation network to access and packaging of the Agri product also depends on the distance of the marketplace from the point of production. By reviewing the literature, it is observed that fuel prices impact the involved transportation cost. The distance between the farm and distribution centers often plays a significant role in determining the market price of the produce. The major decision in the model formulation is the timing of crop sowing and harvesting to fulfill consumer requirements. Thus, the model will enable us to determine the type of transportation, packaging, and storage facilities to be availed by farmers to minimize the farm cost. However, the model focuses only the management of perishable product, the study can be further extended to inculcate both perishable and non-perishable products simultaneously.

By accompanying crop perishability and alternative available in decision space for product distribution the model can be elaborated to determine the profitability of potential customers and exploring new market trends.

\section{REFERENCES}

Abdelaziz, B. (1978). A Mathematical Model for Regional Crop Allocation, Thesis Master of Science in Operations Research, Georgia Institute of Technology, Atlanta, GA, pp. 1-181.

Ahumada, O. and Villalobos, J.R. (2009), "Application of planning models in the agri-food supply chain: a review", European Journal of Operational Research, Vol. 196, No. 1, pp. 1-20. http://dx.doi.org/10.1016/j.ejor.2008.02.014.

Ahumada, O. and Villalobos, J.R. (2011), "A tactical model for planning the production and distribution of fresh produce", Annals of Operations Research, Vol. 190, No. 1, pp. 339-58. http://dx.doi.org/10.1007/s10479-009-0614-4.

Ahumada, O. and Villalobos, R. (2011b). “Operational model for planning the harvest and distribution of perishable agriculture product", International Journal of Production Economics, Vol. 133, No. 2, pp. 677 87.

APS Fulfillment (2017). "What is the difference between inventory management and warehouse management?", available at: https://www.apsfulfillment.com/warehouse-fulfillment/what-is-thedifference-between-inventory-management-and-warehouse-management/ (accessed 22 June 2020).

Benitez, G.B. and Ferreira Lima, M.J.R. (2019). The real options method applied to decision making - an investment analysis. Brazilian Journal of Operations \& Production Management, Vol. 16, pp. 562-71. https://doi.org/10.14488/BJOPM.2019.v16.n4.a2.

Bhuyan, R. 2016. "India jumps 19 places in World Bank's logistics performance index", available at: https://www.livemint.com/Politics/aqBXOSWqMObUMUAffuGH6I/India-jumps-19-places-in-WorldBanks-logistics-performance.html (accessed 22 September 2019). 
Blackburn, J. and Scudder, G. (2009), "Supply chain strategies for perishable products: the case of fresh produce", Production and Operations Management, Vol. 18, pp. 129-37. http://dx.doi.org/10.1111/j.1937-5956.2009.01016.x.Boudahri, F., Aggoune-Mtalaa, W., Bennekrouf, M. et al. (2013). "Application of a clustering based location-routing model to a real agri-food supply chain redesign", in Nguyen, N.T., Trawiński, B., Katarzyniak, R., Jo, G.-S. (Eds.), Advanced Methods for Computational Collective Intelligence. Springer Berlin Heidelberg, Berlin, Heidelberg, pp. 323-331. https://doi.org/10.1007/978-3-642-34300-1_31.

Bureau, O. (2012). "Post-harvest supply chain, poor warehousing woes of agri sector", available at: https://www.thehindubusinessline.com/economy/agri-business/\%E2\%80\%98Post-harvest-supplychain-poor-warehousing-woes-of-agri-sector\%E2\%80\%99/article20514574.ece $\quad$ (accessed 19 September 2019).

Business Standard (2018), "India's food grain storage capacity rises to 877.37 lakh tonnes", Business Standard News. available at: https://www.business-standard.com/article/news-cm/india-s-foodgrain-storage-capacity-rises-to-877-37-lakh-tonnes-118121800914_1.html (accessed 1 October 2020).

Catalá, L.P., Durand, G.A., Blanco, A.M. et al. (2013), "Mathematical model for strategic planning optimization in the pome fruit industry", Agricultural Systems, Vol. 115, pp. 63-71. http://dx.doi.org/10.1016/j.agsy.2012.09.010.

Comisón para la Investigación y Defensa de las Hortalizas de Sinaloa - CIDH (2020). "Agricultural vegetables", available at: http://www.cidh.org.mx/ (accessed 25 June 2020).

CSR Journal. (2018). "Food wastage in india, and what you can do about it", available at: https://thecsrjournal.in/food-wastage-in-india-a-serious-concern/ (accessed 5 August 2020).

Di, W., Wang, J., Li, B., et al. (2011). "A location-inventory model for perishable agricultural product Distribution Centers". In Conference of the 2nd International Conference on Artificial Intelligence, Management Science and Electronic Commerce (AIMSEC), IEEE, USA, pp. 919-22. https://doi.org/10.1109/AIMSEC.2011.6010720.

Ferrer, J.-C., Mac Cawley, A., Maturana, S. et al. (2008), "An optimization approach for scheduling wine grape harvest operations", International Journal of Production Economics, Vol. 112, No. 2, pp. 985-99. https://doi.org/10.1016/j.ijpe.2007.05.020.

Food Corporation of India (2019). Capacity.

Frazzon, E.M., Rodriguez, C.M.T., Pereira, M.M. et al. (2019), "Towards supply chain management 4.0", Brazilian Journal of Operations \& Production Management, Vol. 16, No. 2, pp. 180-91. http://dx.doi.org/10.14488/BJOPM.2019.v16.n2.a2.

He, Y., Huang, H., Li, D. et al. (2018), "Quality and operations management in food supply chains: a literature review", Journal of Food Quality, Vol. 2018, pp. 1-14. http://dx.doi.org/10.1155/2018/7279491.

India, Government of India, Department of Food \& Public Distribution New Delhi (2015). Committee for Strengthening Negotiable Warehouse Receipts by the Warehousing Development and Regulatory Authority in the Country. Warehousing Development and Regulatory Authority, New Delhi.

India, Government of India, Ministry of Agriculture \& Farmers Welfare, Department of Agriculture Cooperation \& Farmers Welfare (2018). Annual repot, Krishi Bhawan, New Delhi.

India. Government of India. Ministry of Consumer Affairs, Food \& Public Distribution. Press Information Bureau (2019), "Wastage of foodgrains". available at: https://pib.gov.in/newsite/PrintRelease.aspx?relid=190609 (accessed 1 October 2020).

Krummel, J. and Su, H. (1996). "Topographic effect and its relation to crop production in an individual field", in Robert, P.C., Rust, R.H. and Larson, W.E. (Eds.), Precision Agriculture. Madison, American Society of Agronomy, Crop Science Society of America, Soil Science Society of America, pp. 273. https://doi.org/10.2134/1996.precisionagproc3.c28.

Kumar, P. (1989), "Crop economics and cropping pattern changes", Economic and Political Weekly, Vol. 24, pp. A-159-66.

Lowe, T.J. and Preckel, P.V. (2004), "Decision technologies for agribusiness problems: a brief review of selected literature and a call for research", Manufacturing \& Service Operations Management, Vol. 6, No. 3, pp. 201-8. http://dx.doi.org/10.1287/msom.1040.0051.

Matanga, G.B. and Mariño, M.A. (1979), "Irrigation planning: 1. Cropping pattern", Water Resources Research, Vol. 15, pp. 672-8. http://dx.doi.org/10.1029/WR015i003p00672. 
Moazzam, M., Garnevska, E., Garnevska, E.V. et al. (2012). “Benchmarking agri-food supply chain networks: a conceptual framework", in Word Business Capability Congress, Auckland, World Business Capability Congress Linked-In Group.

Mogale, D.G., Dolgui, A., Kandhway, R. et al. (2017), "A multi-period inventory transportation model for tactical planning of food grain supply chain", Computers \& Industrial Engineering, Vol. 110, pp. 379-94. http://dx.doi.org/10.1016/j.cie.2017.06.008.

Nier, S., Klein, O. and Tamásy, C. (2019), "Global crop value chains: shifts and challenges in south-north relations", Social Sciences, Vol. 8, No. 3, pp. 85. http://dx.doi.org/10.3390/socsci8030085.

Olena, S. and Maryna, S. (2016), "The role of logistics in agricultural development in Ukraine", Ekonomika i Organizacja Logistyki, Vol. 1, No. 2, pp. 67-77.Onggo, B.S., Panadero, J., Corlu, C.G. et al. (2019), “Agrifood supply chains with stochastic demands: a multi-period inventory routing problem with perishable products", Simulation Modelling Practice and Theory, Vol. 97, pp. 101970. https://doi.org/10.1016/j.simpat.2019.101970.

Osvald, A. and Stirn, L.Z. (2008), "A vehicle routing algorithm for the distribution of fresh vegetables and similar perishable food", Journal of Food Engineering, Vol. 85, pp. 285-95. http://dx.doi.org/10.1016/j.jfoodeng.2007.07.008.

Ranade, C.G. (1980), "Impact of cropping pattern on agricultural production", Indian Journal of Agricultural Economics, Vol. 35, No. 2, pp. 85-93.

Rong, A., Akkerman, R. and Grunow, M. (2011), "An optimization approach for managing fresh food quality throughout the supply chain", International Journal of Production Economics, Vol. 131, pp. 421-9. http://dx.doi.org/10.1016/j.ijpe.2009.11.026.

Scare, R.F., Lopes, F.F., Afonso, R.A., et al. (2019). The Management Challenges of Brazilian Grain Producers. IFAMA, Minneapolis.

Schotzko, R.T. and Hinson, R.A. (2000), "Supply chain management in perishables: a produce application", Journal of Food Distribution Research, Vol. 31, No. 2, pp. 17-25.

Simantov, H. (2019). "What is logistics management?", available at: https://www.aims.education/studyonline/what-is-logistics-management/ (accessed 9 September 2019).

Subramani, M.R. (2019), "Why priority should be given to modernising foodgrain storage", available at: https://swarajyamag.com/economy/why-priority-should-be-given-to-modernising-foodgrainstorage (accessed 1 October 2020).

Warrick, A.W. and Gardner, W.R. (1983), "Crop yield as affected by spatial variations of soil and irrigation", Water Resources Research, Vol. 19, pp. 181-6. http://dx.doi.org/10.1029/WR019i001 p00181.

Welby, E.M. and McGregor, B. (2004). Agricultural Export Transportation Handbook. Agricultural Marketing Service, United States Department of Agriculture, USA.

Yang, Y., LIn, X., Zhou, L. et al. (1996), "Sustainable groundwater management under impacts of urban growth in a developing country - a case study in the city of Shijadran, China", Environmental Management and Health, Vol. 10, pp. 18-30. http://dx.doi.org/10.1108/09566169910257103.

Zhang, W. and Wilhelm, W.E. (2011), "OR/MS decision support models for the specialty crops industry: a literature review", Annals of Operations Research, Vol. 190, pp. 131-48. http://dx.doi.org/10.1007/s10479-009-0626-0.

Author contributions: Authors contributed equally for the work conducted 